\title{
A Study on Awareness about the Impact of National Education Policy-2020 Among the Stakeholder of Commerce and Management Disciplinary
}

\author{
L. Devi and Cheluvaraju
}

\begin{abstract}
National Education Policy-2020 visualized to provide a quality education which is beneficial to meet the growing economy in India. The new policy is aiming to achieve majorly three aspects such as highest quality, equity, and integrity in the education system from schooling to higher education. Commerce and management education play an important role in the country's economy as it effects all the sectors like manufacturing, service industry, research and development, banking etc. in all the field finance is the nerve system and knowledge to manage finance is dealt with commerce and management. The current education policy existing in India are concentrating majorly on theoretical aspects which lacks the practical training among the students i.e., the major drawback for meeting the global job opportunities. Therefore, the National Education Policy-2020 is aiming to develop creative potential, skill and analytical thinking which are the need in the global job market is. Hence all the curriculum of commerce and management should be redesigned based on the outcome based education, where the stakeholders can know in prior what they are going to learn and how it is beneficial to develop themselves to meet the future changes in economy.
\end{abstract}

Index Terms - NEP, National education policy- 2020, Education sector, Commerce, Management.

\section{INTRODUCTION}

A National Education policy is a comprehensive structure to guide the development of education in India. The need for a policy was initiated in 1964 when Congress MP Siddheshwar Prasad disparaged the then government for requiring a vision and philosophy for the reform in education. During the same period, a 17 member Education Commission, led by the UGC Chairperson D S Kothari, was founded to draft a national and harmonized policy on education. Based on the proposals of the Commission, Parliament approved the first education policy in 1968.

A new NEP generally comes along with few decades. India had three reforms to date. The first policy came in 1968 and the second reform in 1986, under Indira Gandhi and Rajiv Gandhi correspondingly; the NEP of 1986 had been revised in 1992 during the period of P V Narasimha Rao has a Prime Minister. The third NEP was released on 29th July 2020, Wednesday by the Prime Ministership of Narendra Modi.

The NEP recommends sweeping changes including starting up of Indian higher education sector to foreign universities, disassembling of the UGC and All India Council for Technical Education (AICTE), establishing a four-year multidisciplinary undergraduate program with various exit options, and discontinuation of the M Phil program. In school education, the policy concentrates on overhauling the core curriculum, "easier" Board exams, a decline in the syllabus to maintain "core essentials" and drive on "experiential learning and critical thinking".

In a momentous shift from the 1986 policy, which strapped for a $10+2$ structure of school education, the new NEP-2020 pitches for a " $5+3+3+4$ " scheme corresponding to the age sets 3-8 years (foundational phase), 8-11 (preparatory), 11-14 (middle), and 14-18 (secondary). That fetches early childhood education (also familiar as pre-school education intended for children of ages 3 to 5) underneath the influence of formal schooling. The mid-day meal program will be stretched to pre-school children. The NEP declares students till Class 5 should be educated in their mother tongue or regional language.

The policy also recommends phasing out of all organizations offering single streams and that all universities and colleges must aim to become multidisciplinary by 2040 .

The National Education Policy 2020 foresees inclusive and justifiable quality education while targeting to address the rising developmental imperatives of India. With the fastgrowing employment landscape and universally diverse ecosystem in education sector, it is becoming acute that one should not only learn but it should also know how to learn.

Change in education reforms are engaged in such a way that learning outcomes convey the highest quality, integrity, and equity into the system right from schooling till higher education.

The emphasis of the policy offers multidisciplinary and holistic education by absorbing knowledge of several arts (popularly known as generous arts) in the course. Emphasis needs to be specified on Theoretical understanding through pedagogies that highlight on communication, discussion, debate, research, and cross-disciplinary and interdisciplinary thinking.

Commerce and Management education may require continuous revision and revamp of the core curriculum which will progress the creative potential of each student and create new career growth occasions based on changing industrial and societal demands. The curriculum necessities to be periodically revisited over Curriculum Conclaves through 
involvement of various stakeholders to capture their varying expectations and also to encounter the requirements of the education policy.

Education in Commerce and Management required to be Outcome-Based Education at Undergraduate and Postgraduate stages with provision for Choice Based Credit System (CBCS). Outcome-based education defines Program Educational Objectives (PEOs), Program Objectives (POs) and Course Objectives (COs) for every program and student progression is assessed based on their achievement status. Core subjects can be a blended form of theory and practical subjects. Practical subjects should give students good exposure using various tools and software applications applicable to commerce and management education. Open elective courses must offer knowledge and skills among diverse areas that creates an opportunity for holistic education and Specialization (major) subjects matters to create a concentration on various functional areas.

Problem Based Learning requests to be integrated into the curriculum for the better understanding of several concepts in business and commerce.

Department of Commerce, MAHE has established this structure in all its curriculums at Undergraduate and Post Graduate levels which had been very beneficial for all the stakeholders.

Offering undergraduate courses with chances to major in specializations such as Accounting, Insurance, Banking, Economic studies, Family Business, Financial markets, Logistics, Marketing, Human resources, and Business Analytics will deliver a grounding in different functional segments of Business and focus the individuals on a career in those fields. Offering global accounting accreditation such as ACCA, CIMA, CMA, etc. implanted in the curriculum will deliver students an opportunity to comprehensive their degree along with a professional accreditation, which will provide them the additional skills and knowledge while they approach the corporate ecosphere. Another important factor in developing and designing a program is the involvement of industry partners.

\section{A. Implementation of NEP}

The NEP only offers a broad direction and is not compulsory to follow. Since education is a synchronized subject (both the Centre and the state governments can make laws on it), the National educational reforms proposal can only be executed collaboratively by the Centre and states. This may not happen instantaneously. The incumbent government has marked a target of 2040 to establish the entire policy. Sufficient finance is also vital; the 1968 NEP was restricted by a shortage of funds.

The government policies to set up subject-wise boards with members from appropriate ministries at both the central and state government levels to develop operational plans of each aspect of the NEP. The policy will list out actions to be implemented by multiple bodies, comprising the HRD Ministry, state Education Departments, school Boards, NCERT, Central Advisory Board of Education and National Testing Agency, and others. Planning will be monitored by a yearly joint criticism of progress against targets established.

Major contributors to policy failure:

1. Overly optimistic expectations: Due to above positivity there is and under assessment of cost and time for a strategy to be implemented.

2. Implementation in dispersed governance: Once the procedure is tailor made to fit all nevertheless of their constraints.

3. Inadequate cooperative policymaking: Lack of cooperation with all the stakeholders

4. Vagaries of the political process: The policy makers focus on the short-term outcome as they don't want to be marked for the failure and take recognition of the legislation that is approved rather than its implementation.

\section{B. Factors to successfully implement the NEP}

1. To implement NEP effectively at all levels the government will be required to create stakeholder incentives so that the execution is smooth and uniform.

2. Formulate gadgets in the form of institutional mechanisms, legal, policy and regulatory authority.

3. Build reliable information repositories.

4. Develop flexibility across HEIs, regulatory bodies and also government agencies.

5. Develop reliability through transparent actions and contribution of all stakeholders.

6. Develop sound moralities of management.

\section{REVIEW OF LITERATURE}

Aithal S. and SubraJyothsna A. [1] analyzed the new education policy 2020 effectiveness in achieving the objectives. The study highlighted the overview of National education policy 2020 and compared with an existing education policy through which they found the drawbacks lined up with an existing education policy and trends which are going to be created with the new education policy 2020 in the future. The study had also provided major suggestions for the educational departments regarding implementation of new education policy 2020 like providing appreciation regarding article publishing, faculty training and Ph.D mandatory so on.

Praveen J. and Pooja P. [2], examined the updates done by the ministry of education from last three educational policy and it has also criticized the factors which is contributing for holistic development in the education sector. The study had concentrated on the changes to be adopted by the educational institutions, universities, colleges etc. for the effective implementation of National education policy 2020 .

Muskan S. [3] highlighted on the national education policy 2020. The researcher concentrated on all the segments of education sector and their effects on the economy. The study majorly described the national education policy from the time of announcement done by the prime minister till the various challenges to be faced by the educational institutions in adopting the changes in their work environment based on the National education policy 2020.

\section{Statement OF THE PROBLEM}

The new education policy to be adopted is emerging various challenges for the stakeholders which includes, universities, Colleges, Schools, Teaching faculty, students etc. the entire educational ecosphere has to be revamped in 
the current year based on the NEP 2020, the stakeholders may find difficult to adopt to the changes since they are not aware about the functioning of NEP 2020. The stakeholders must understand benefits which are listed with the NEP 2020. Hence this study aims to analyze the benefits derived from the NEP 2020 for the field of Commerce and Management so that the Teaching community can understand the outcome and work with the NEP 2020 effectively to attain the objective.

\section{OBJECTIVES OF THE STUdY}

- $\quad$ To understand the National Education policy 2020.

- To analyze the effect of NEP 2020 on Commerce and Management disciplinary.

- To compare the outcome of existing NEP and NEP 2020.

- To suggest the institutions based on the Research design

- The research design used in this study is empirical type of research.

\section{Research Methodology}

\section{A. Population}

The study includes the stakeholders of various educational institutions located in Bengaluru.

\section{B. Sample Size}

The study is conducted on a sample size of hundred respondents from Bengaluru.

\section{Method of Data Collection}

The study made use of both primary and secondary data. Primary data was collected through a structured questionnaire from the respondents. Secondary data was collected through various web sources and expert opinion.

\section{Sampling Technique}

A convenient sampling technique was used to select the respondents for the study.

\section{E. Analysis of Data}

The data collected has been analyzed using simple percentage analysis. The study also analyzed the data using Chi-square test to find the effectiveness of the new education policy among the teaching faculties and students.

\section{HYPOTHESES}

Two hypotheses have been framed to identify the relation between dependent and independent variables.

H0: There is no significant impact of NEP 2020 on stakeholders of commerce and management discipline.

H1: There is significant impact of NEP 2020 on stakeholders of commerce and management discipline.

\section{LIMITATIONS OF THE STUDY}

- Lack of secondary source of information.

- The study is limited only to Bengaluru.

- The study is restricted to only 100 respondents.
- Time constraint.

- The result of the study cannot be generalized.

VIII. RESULTS

TABLE 1: DEMOGRAPHIC PROFILE OF RESPONDENTS

\begin{tabular}{cc}
\multicolumn{2}{c}{ Demographic Distribution } \\
\hline Particulars & Percentage \\
\hline Gender: Male & 47 \\
Gender: Female & 53 \\
Age: 23-28yrs & 39 \\
Age: $29-35 \mathrm{yrs}$ & 25 \\
Age GT: 35yrs & 9 \\
Age LT: 22yrs & 27 \\
Education: Ph.D & 19 \\
Education: PG & 54 \\
Education: UG & 27 \\
Designation: Professor & 5 \\
Designation: Associate Professor & 4 \\
Designation: Assistant Professor & 49 \\
Designation: Lecturer & 15 \\
Designation: Student & 27 \\
\hline
\end{tabular}

The above Table 1 describes the profile of the stakeholders of the education sectors who are majorly affected by the NEP2020. The table signifies the study has conducted with the total 100 samples, including students, Lecturers, Assistant professor, Associate professor, Professor who are well educated and having an experience with teaching minimum of 3 years. Hence the findings drawn from this study would be beneficial for the adoption of NEP-2020 without many complications.

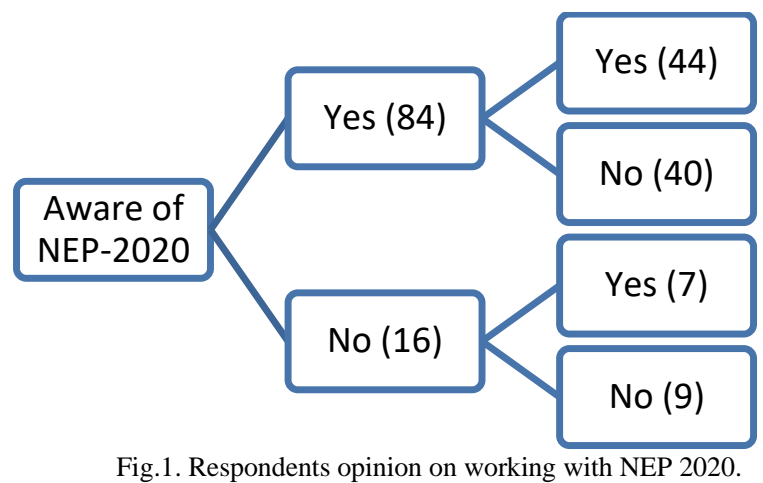

The Fig. 1 represents the opinion of the stakeholders regarding awareness of NEP 2020 and working with NEP 2020. Among 100 respondents 84 respondents are aware about the National Educational Policy 2020 out of which 44 respondents feel the working with NEP 2020 is easier than Current NEP. The 16 respondents who are not aware of NEP 2020 even among these 7 respondents have an opinion working with NEP 2020 may be easier but still 49 respondents overall feel difficult with NEP 2020.

The Fig. 2 represents the opinion of stakeholders regarding requirement of the skill set development of the stakeholders of the commerce and management discipline based of NEP 2020. Figure signifies $30 \%$ of the overall samples strongly believe the skills must be developed to work with NEP 2020. $16 \%$ of the overall sample stands neutral in disclosing their opinion due to lack of knowledge. $14 \%$ of the overall sample believe with the present skill set we can work efficiently with the NEP 2020. 


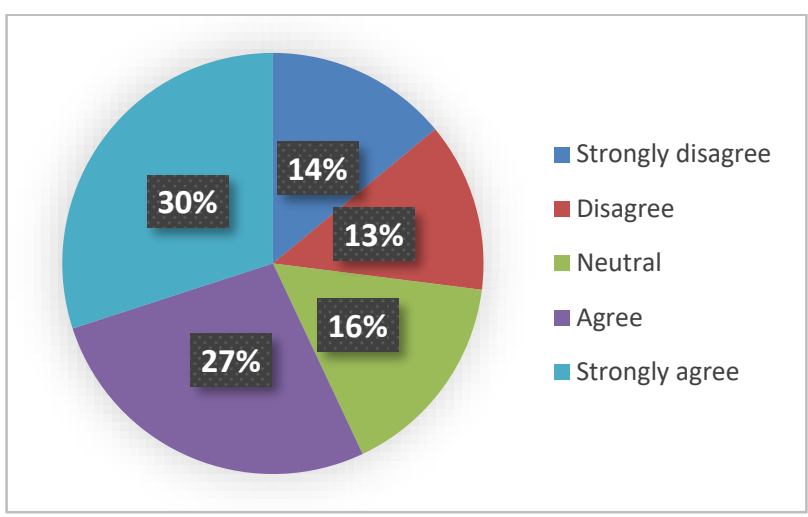

Fig. 2. NEP requires skill set development among the stake holders.
The Table 2 represents the respondent's opinion on the drawback of current National Education Policy. It signifies 73 respondents had accepted that current NEP are not much concentrating on the carrier growth of students. 67 respondents had felt NEP at present are majorly subject oriented. 77 respondents had identified curriculum under NEP are based on CBCS. 75 respondents have an opinion current NEP is based on memorizing capacity of students. 72 stakeholders felt NEP at present is not meeting the requirements of the industry. 69 respondents have an opinion NEP is not attracting foreign students. 72 respondents identified NEP is rigid and it is not allowing students to opt courses of various discipline.

TABLE 2: RESPONDENTS OPINION ON THE DRAWBACK OF THE CURRENT NEP

\begin{tabular}{|c|c|c|c|c|c|c|}
\hline Particulars & $\begin{array}{l}\text { Strongly } \\
\text { Disagree }\end{array}$ & Disagree & Neutral & Agree & $\begin{array}{c}\text { Strongly } \\
\text { Agree }\end{array}$ & $\begin{array}{c}\text { Total } \\
\text { Sample }\end{array}$ \\
\hline It is lacking to focus on students carrier growth & 14 & 8 & 5 & 34 & 39 & 100 \\
\hline It is mainly subject oriented & 6 & 11 & 16 & 31 & 36 & 100 \\
\hline The curriculum is based on CBCS & 7 & 7 & 9 & 36 & 41 & 100 \\
\hline Current education policy outcome is based on memorizing & 8 & 7 & 10 & 36 & 39 & 100 \\
\hline It is not meeting the industrial requirements & 5 & 6 & 17 & 29 & 43 & 100 \\
\hline It is not much attracting foreign students & 9 & 10 & 12 & 38 & 31 & 100 \\
\hline It doesn't allow students to opt courses of various discipline & 12 & 7 & 9 & 33 & 39 & 100 \\
\hline
\end{tabular}

TABLE 3: CHI-SQUARE ANALYSIS TABLE

\begin{tabular}{|c|c|c|c|c|}
\hline Particulars & Observation & Expected & $\mathrm{O}-\mathrm{E}$ & $(\mathrm{O}-\mathrm{E})^{2} / \mathrm{E}$ \\
\hline NEP - 2020 builds road map for students to choose their carrier field in early age & 50 & 49 & 1 & 0.020408163 \\
\hline NEP - 2020 will be outcome based learning & 44 & 49 & -5 & 0.510204082 \\
\hline NEP- 2020 aims to develop analytical skills among the students & 54 & 49 & 5 & 0.510204082 \\
\hline NEP-2020 aims to bring conceptualize learning & 55 & 49 & 6 & 0.734693878 \\
\hline NEP -2020 develops skillset among the students that meets industrial demands & 51 & 49 & 2 & 0.081632653 \\
\hline NEP - 2020 opens market for educational sector at global level & 43 & 49 & -6 & 0.734693878 \\
\hline \multirow[t]{2}{*}{ NEP - 2020 allows students to opt Creative combination of subjects } & 52 & 49 & 3 & 0.183673469 \\
\hline & 349 & & & 2.775510204 \\
\hline
\end{tabular}

$\mathrm{H}_{0}$ : There is no significant impact of NEP 2020 on stakeholders of commerce and management discipline.

$\mathrm{H}_{1}$ : There is significant impact of NEP 2020 on stakeholders of commerce and management discipline.

$\alpha=0.05$

$1-\alpha=0.95$

Degree of freedom $=7-1=6$.

Chi square value $=2.77$.

Critical value $(\alpha=0.05$ d.f $=6)=1.635$.

Decision: Chi square value is more than critical value $(2.77>1.635)$ hence $\mathrm{H}_{0}$ is rejected.

The above Table 3 represents the chi square analysis a nonprobability test which is conducted to test the hypothesis of independent variables. The chi square analysis proved that NEP 2020 is going to impact the stakeholders of the commerce and management discipline majorly. Hence all the stakeholders must undergo study to enhance the knowledge of NEP 2020 working so that they can adopt the NEP 2020 easily without much error and work effectively for the growth of Indian economy.

\section{SugGestions}

The stakeholders must start analyzing the NEP 2020 working factors so that it helps to identify the skills required for working with NEP 2020. The stakeholders must develop the required skills and adopt the NEP2020 positively so that it leads to faster growth of economy. Students community must analyze their skill set before opting for the course because the NEP 2020 aims for outcome based learning if the students opt for the course based on their skills then they can achieve their goals faster. There is a wide scope for the study on NEP 2020 because the major group of people are still lacking the knowledge on the working of NEP 2020 hence the researchers must undergo enormous research under this field to improve the knowledge among the stakeholders which ultimately leads to adoption of NEP 2020 at greater speed and leads to development of economy.

\section{CONClusion}

The study had enhanced the knowledge on NEP 2020 impact on the stakeholders of commerce and management discipline in a broader sense. The comparative study on the current NEP and NEP 2020 has pointed out the drawbacks of the current NEP which was affecting the growth of Indian economy and affecting the youths in achieving their goals. The NEP 2020 leads all the stakeholders to meet the industrial demands at national and global level so that the standard of living and the overall economic growth will be achieved significantly. Any changes in the present scenario will have both positive and negative impacts hence we must concentrate more on the positive impacts and adopt it effectively and work efficiently for the welfare of the country. 


\section{REFERENCES}

[1] P.S. Aithal \& Shubrajyotsna Aithal,(2020), "Analysis of the Indian National Education Policy 2020 towards Achieving its Objectives", International Journal of Management,Technology, and Social Sciences (IJMTS),Vol. 5, Issue. 2, pp. 19-41.

[2] Praveen Jha, Pooja Parvati, (2020), "Long on Rhetoric and Short on substance National Education Policy, 2020", Economic and Political review journal, Vol. 55, Issue No. 34.

[3] Muskan Sha, (2020), "National Education Policy 2020", International journal of research.

[4] https://indianexpress.com/article/explained/reading-new-educationpolicy-india-schools-colleges-6531603/.

[5] https://www.mhrd.gov.in/sites/upload_files/mhrd/files/NEP_Final_En glish_0.pdf.

[6] https://www.hindustantimes.com/education/nep-2020 implementation-of-new-education-policy-in-our-educationsystem/story-bw4OiekFCamI7NPoNkgAoJ.html.

[7] https://www.indiatoday.in/education-today/featurephilia/story/nep2020-what-are-the-career-growth-opportunities-in-commerce-streamby-introduction-of-new-curriculum-1731131-2020-10-13.

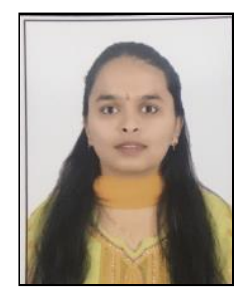

Devi L. pursuing Ph.D from Kuvempu University, Shivamogga, Karnataka, India. Awarded Master of Commerce and Bachelor of Commerce degree from Bangalore University, Karnataka, India. Specialized in Marketing, Accounting and Taxation.

She is working as an Assistant Professor at Krupanidhi College of Commerce and Management, Bangalore, Karnataka, India Previously for the period of 3years worked as an Assistant Professor at Jain (Deemed to be University), Bangalore, Karnataka, India.

She is contributing significantly to the field of research published 12 research paper in the various national and international journals. She attended more 10 FDP and workshops on various current trends, presented research study in various national and international conferences held in different colleges at Bangalore, Karnataka, India.

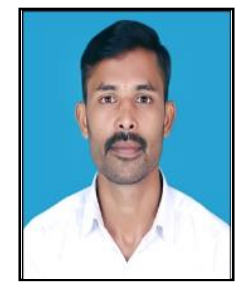

Cheluvaraju Awarded Master of Commerce and Bachelor of Commerce degree from Bangalore University, Karnataka, India. Specialized in Accounting and Taxation. He cleared Karnataka State Eligibility Test for Assistant Professor.

$\mathrm{He}$ is working as an Assistant Professor at Krupanidi College of Commerce and Management, Bangalore, Karnataka, India. He has Nearly 3 years of Experience in Corporate and for the period 2 years and 6 months worked as an Assistant Professor at (Florence and Oxford College) Bangalore, Karnataka, India. He has participated in various seminars, Workshops, and FDPs. 